\title{
TREATMENT OF UNICAMERAL BONE CYSTS IN CHILDREN: A COMPARATIVE STUDY
}

\author{
Bojan Bukva ${ }^{1,2}$, Goran Vrgoč $\check{c}^{3,4}$, Dušan Abramović ${ }^{1}$, Siniša Dučić ${ }^{1,2}$, \\ Iva Brkić ${ }^{5}$ and Tomislav Čengić ${ }^{6}$ \\ ${ }^{1}$ University Children's Hospital, Belgrade, Serbia; ${ }^{2}$ Faculty of Medicine, University of Belgrade, Belgrade, Serbia; \\ ${ }^{3}$ Department of Orthopedic Surgery, Sveti Duh University Hospital, Zagreb, Croatia; \\ ${ }^{4}$ Faculty of Kinesiology, University of Zagreb, Zagreb, Croatia; \\ ${ }^{5}$ Department of ENT and Head and Neck Surgery, Sveti Duh University Hospital, Zagreb, Croatia; \\ ${ }^{6}$ Department of Traumatology, Sestre milosrdnice University Hospital Centre, Zagreb, Croatia \\ SUMMARY - Unicameral bone cysts (UBC) are benign bone tumor-like lesions. Mostly they are \\ located in the metaphyseal-diaphyseal region of long bones in children and adolescents. The etiology \\ of UBC is still unclear. There is no consensus about the protocol of UBC treatment. The aim of this \\ study was to evaluate the effectiveness of three different techniques for the treatment of UBC. This \\ study included 129 pediatric patients with UBC treated at University Children's Hospital in Belgrade \\ during the 8 -year period. The mean follow up was 7.14 years. The following parameters were observed: \\ gender, age, site, length of cyst, cyst index, cortical thickness, presentation of pathologic fracture, heal- \\ ing of cyst, treatment complications and length of hospitalization. These parameters were correlated to \\ three treatment modalities, i.e. intracystic methylprednisolone acetate injection (group 1), curettage \\ with bone grafting (group 2) and osteoinductive procedure using demineralized bone matrix (group \\ 3). We found statistically significant differences in healing of the cysts and length of hospital treat- \\ ment between groups 1 and 2, and between groups 2 and 3 . In conclusion, complete healing of UBC \\ can be achieved only using open surgery procedure. Intracystic methylprednisolone acetate instillation \\ can be considered a good option for initial treatment of UBC.
}

Key words: Bone cysts; Child; Injections, intralesional; Bone transplantation; Bone matrix

\section{Introduction}

Various diseases can cause local bone defects in pediatric population. Despite the heterogeneous mechanism of occurrence, bone cysts present a poorly biomechanical locus and it can lead to pathologic fracture ${ }^{1}$.

Unicameral bone cysts (UBC) are benign bone tumors in children. They are located in the metaphysisdiaphysis zone of long bones. The UBC are mostly asymptomatic and diagnosed incidentally. The etiology of UBC is still unclear; trauma, inflammation and venous obstruction of bones have been proposed ${ }^{2,3}$.

Correspondence to: Goran Vrgoč, $M D$, Sveti Duh University Hospital, Sveti Duh 64, HR-10000 Zagreb, Croatia

E-mail: gvrgoc@gmail.com

Received December 19, 2017, accepted April 18, 2018
The aim of this study was to compare three different methods of treatment of UBC, i.e. intracystic injection of methylprednisolone acetate (MPA) (Scaglietti procedure), curettage with bone grafting (autoosteoplastic procedure) and osteoinductive procedure using demineralized bone matrix (DBM).

\section{Patients and Methods}

This retrospective study included 129 pediatric patients aged 8-17 and treated at University Children's Hospital in Belgrade, Serbia, during 8-year period (from January 2007 to January 2014). Patients were divided into three groups according to the method of treatment, as follows: group 1 treated with intracystic MPA injection (according to Scaglietti procedure); 
group 2 treated with curettage and bone grafting; and group 3 treated with osteoinductive procedure using DBM.

The inclusion criterion for participation in the study was pediatric patient below age 18 diagnosed with UBC. The study included all patients with or without a history of previous treatment or previous fracture. The exclusion criteria were malignant tumor presentation, bone marrow disease, chronic autoimmune disease with steroid use, and patients on chemotherapy or radiotherapy.

The following parameters were observed: gender (male/female), age ( $\leq 8$ years and $>8$ years), site (long or short bone), cyst diameter $(\leq 5 \mathrm{~cm}$ or $>5 \mathrm{~cm})$, cyst index (area of the cyst/diaphysis diameter), cortical thickness ( $\leq 2 \mathrm{~mm}$ and $>2 \mathrm{~mm}$ ), presentation of pathologic fracture (yes or no), healing of the cyst (months), complications (yes or no), and length of hospital stay (days). All parameters were evaluated according to radiological findings in anteroposterior and lateral views.

Patients treated with curettage and bone grafting and patients treated by osteoinductive procedure (groups 2 and 3) had histopathologic verification of $\mathrm{UBC}$ but those treated by steroid injection did not.

Clinical data were collected from patient clinical records, for which the respective informed consent was obtained. The $\chi^{2}$-test, Fisher exact test and regression analysis were used to test the correlation between those three groups of patients. The level of statistical significance was set at $\mathrm{p}<0.05$.

\section{Surgical techniques}

\section{Group 1: Steroid injection-Scaglietti method ${ }^{4}$}

We used two 11-gauge aspiration needles to aspirate and wash the cyst under x-ray control. After washing the cyst, we inserted $80-180 \mathrm{mg}$ of MPA into the cyst ( $3 \mathrm{mg}$ per $\mathrm{cm}^{3}$ of cyst). The procedure was performed three times at three-month interval between the procedures.

\section{Group 2: Curettage and bone grafting}

We used standard approach according to the cyst location. The cortex above the cyst was opened with four to eight drill holes. Using a chisel, we connected the holes and removed bone cortex. After removing fluid from the cyst, the membrane of the cyst was curetted using various curettes (straight and curved). After curettage, we used autologous bone graft taken from the iliac crest to fill the cyst and improve healing. The specimen obtained from the cyst was sent for histopathologic analysis.

\section{Group 3: Osteoinductive procedure \\ using demineralized bone matrix}

The standard approach to the cyst was used including opening the bone cortex, evacuation of the fluid and curettage of the cyst. The specimen obtained from the cyst was sent for histopathologic analysis. DBM pellets were used to induce healing of the cyst. We used cortical sterile allograft tissue, cortical dust of 250-420 mic (Implant Services, Cortically Sterile A1lograft Tissue, Osteotech Inc., New Jersey, USA).

\section{Postoperative treatment and radiological follow up}

Postoperative management varied according to the location and volume of the cyst, presence of fracture and method of treatment, ranging from simple dressing, cast immobilization, non-weight bearing and activity restriction.

Radiographs were obtained on day 1 after the surgery, at three-month follow up, and then every six months. Healing of the cyst was followed up by use of the radiographic Neer and Cole four-grade rating system ${ }^{5,6}$. According to this system, grade $\mathrm{I}$ is defined as complete obliteration of the cyst, grade II as bone filling but with the presence of some opaque areas, grade III as visible lucent and multi-locular areas, and grade IV as postoperative signs being unchanged ${ }^{5}$. Grades I and II were considered as cyst healing.

Limitations of the study were the lack of cyst analysis against previous methods of treatment and of complication analysis, and exclusion of patients treated by other methods of treatment (drainage procedures using Kirschner wires, titanium elastic nail or cannulated screws).

\section{Results}

The study included 93 (72.1\%) boys and 36 (27.9\%) girls treated during 8-year period (from January 2006 to January 2014). The mean age of study patients was 11.07 (range, 7-17) years. The majority of our patients were aged $>8$ years $(79.8 \%)$ and had their long bones affected (89.1\%). The patients were divided into three groups according to treatment options, as follows: 65 (50.4\%) patients treated with intracystic MPA injec- 
Table 1. Descriptive parameters of study patients

\begin{tabular}{|c|c|c|c|c|c|}
\hline Study variable & $\begin{array}{l}\text { Total } \\
(\mathrm{N}=129)\end{array}$ & \begin{tabular}{|l|} 
Intracystic \\
steroid \\
injection group \\
$(\mathrm{n}=65)$ \\
\end{tabular} & $\begin{array}{l}\text { Curettage and } \\
\text { bone grafting } \\
\text { group }(n=40)\end{array}$ & $\begin{array}{l}\text { Osteoinductive } \\
\text { procedure using } \\
\text { demineralized bone } \\
\text { matrix group }(\mathrm{n}=24) \\
\end{array}$ & $p$ value* \\
\hline Categorical variable & n (\%) & n (\%) & n (\%) & $\mathrm{n}(\%)$ & \\
\hline $\begin{array}{l}\text { Age }(\mathrm{yrs}): \\
\leq 8 \\
>8\end{array}$ & $\begin{array}{l}26(20.2) \\
103(79.8)\end{array}$ & $\begin{array}{ll}11 & (16.9) \\
54 & (83.1)\end{array}$ & $\begin{array}{ll}11 & (27.5) \\
29 & (72.5)\end{array}$ & $\begin{array}{l}4(16.7) \\
20(83.3)\end{array}$ & 0.378 \\
\hline $\begin{array}{l}\text { Gender: } \\
\text { Male } \\
\text { Female }\end{array}$ & $\begin{array}{ll}93 & (72.1) \\
36 & (27.9)\end{array}$ & $\begin{array}{l}47(72.3) \\
18(27.7)\end{array}$ & $\begin{array}{l}29(72.5) \\
11(27.5)\end{array}$ & $\begin{array}{l}17(70.8) \\
7(29.2)\end{array}$ & 0.988 \\
\hline $\begin{array}{l}\text { Bone type: } \\
\text { Long bone } \\
\text { Short bone }\end{array}$ & $\begin{array}{l}115 \text { (89.1) } \\
14(10.9)\end{array}$ & $\begin{array}{l}65(100.0) \\
0(0.0)\end{array}$ & $\begin{array}{l}28(70.0) \\
12(30.0) \\
\end{array}$ & $\begin{array}{l}22(91.7) \\
2(8.3)\end{array}$ & $<0.001$ \\
\hline $\begin{array}{l}\text { Cyst length: } \\
\leq 5 \mathrm{~cm} \\
>5 \mathrm{~cm}\end{array}$ & $\begin{array}{l}123(95.3) \\
6(4.7)\end{array}$ & $\begin{array}{l}64(98.5) \\
1(1.5)\end{array}$ & $\begin{array}{l}40(100.0) \\
0(0.0)\end{array}$ & $\begin{array}{l}19(79.2) \\
5(20.8)\end{array}$ & $<0.001$ \\
\hline $\begin{array}{l}\text { Cortical thickness: } \\
\leq 2 \mathrm{~mm} \\
>2 \mathrm{~mm}\end{array}$ & $\begin{array}{ll}46 & (35.7) \\
83 & (64.3) \\
\end{array}$ & $\begin{array}{ll}23 & (35.4) \\
42 & (64.6)\end{array}$ & $\begin{array}{l}10(25.0) \\
30 / 75.0)\end{array}$ & $\begin{array}{l}13(54.2) \\
11(48.8)\end{array}$ & 0.062 \\
\hline $\begin{array}{l}\text { Presentation of pathologic fracture: } \\
\text { Yes } \\
\text { No }\end{array}$ & $\begin{array}{l}24(18.6) \\
105(81.4)\end{array}$ & $\begin{array}{l}8(12.3) \\
57(87.7)\end{array}$ & $\begin{array}{l}6(15.0) \\
34(85.0)\end{array}$ & $\begin{array}{l}10(41.7) \\
14(58.3)\end{array}$ & 0.005 \\
\hline $\begin{array}{l}\text { Complications: } \\
\text { Yes } \\
\text { No }\end{array}$ & $\begin{array}{l}9(7.0) \\
120(93.0)\end{array}$ & $\begin{array}{l}0(0.0) \\
65(100.0)\end{array}$ & $\begin{array}{l}3(7.5) \\
37(92.5)\end{array}$ & $\begin{array}{l}6(25.0) \\
18(75.0)\end{array}$ & $<0.001$ \\
\hline $\begin{array}{l}\text { Numerical variable } \\
\text { Cyst index } \\
\text { Cyst healing (months) } \\
\text { Length of hospital stay (days) }\end{array}$ & $\begin{array}{l}\text { Mean } \pm \text { SD } \\
0.77 \pm 0.13 \\
24.86 \pm 7.57 \\
6.41 \pm 4.41\end{array}$ & $\begin{array}{l}\text { Mean } \pm \text { SD } \\
0.78 \pm 0.10^{\mathrm{a}, \mathrm{b}, \mathrm{c}} \\
29.78 \pm 4.84^{\mathrm{a}, \mathrm{b}} \\
3.23 \pm 1.16^{\mathrm{a}, \mathrm{b}}\end{array}$ & $\begin{array}{l}\text { Mean } \pm \text { SD } \\
0.70 \pm 0.15 \\
20.22 \pm 4.85 \\
9.40 \pm 2.98\end{array}$ & $\begin{array}{l}\text { Mean } \pm \text { SD } \\
0.85 \pm 0.11 \\
19.25 \pm 8.66 \\
9.92 \pm 5.67\end{array}$ & $\begin{array}{l}<0.001 \\
<0.001 \\
<0.001\end{array}$ \\
\hline
\end{tabular}

* $\mathrm{p}<0.05$ (two-sided); ${ }^{a}$ significant differences between intracystic steroid injection group and curretage and bone grafting group; bsignificant differences between intracystic steroid injection group and osteoinductive procedure using demineralized bone matrix group; 'significant differences between curretage and bone grafting group and osteoinductive procedure using demineralized bone matrix group.

tion (group 1); 40 (31\%) patients treated with curettage and autologous bone grafting (group 2); and 24 (18.6\%) patients treated with osteoinductive procedure using DBM (group 3).

According to the method of treatment, statistical significance was found for the site of affection, length of the cyst, presentation of pathologic fracture before treatment initiation and complication rate (Table 1).

Also, we found statistically significant differences in cyst healing and length of hospital stay between the intracystic MPA injection group (group 1) and curettage and autologous bone grafting group (group 2), as illustrated in Table 1 . The same variables yielded significant differences between the curettage and autologous bone grafting group (group 2) and osteoinductive procedure using DBM group (group 3).

Table 2 shows a statistically significant correlation between healing of the cyst and length of hospital stay according to treatment options. The length of hospital stay was shortest in patients treated by MPA injection 
Table 2. Regression analysis according to group type and independent variables

\begin{tabular}{|l|l|l|l|}
\hline Study variable & Type of treatment \\
\hline & $\beta$ unstandardized coefficient $(95 \% \mathrm{CI})$ & $\mathrm{p}$ value & Collinearity statistics \\
\hline Age & $0.15(-0.08$ to 0.38$)$ & 0.217 & 1.15 \\
Gender & $-0.05(-0.24$ to 0.18$)$ & 0.659 & 1.02 \\
Bone type & $-0.19(-0.50$ to 0.05$)$ & 0.197 & 1.48 \\
Diameter of the cyst & $0.56(-0.43$ to 1.36$)$ & 0.183 & 1.40 \\
Cortical thickness & $0.10(-0.10$ to 0.31$)$ & 0.340 & 1.55 \\
Presentation of pathologic fracture & $-0.10(-0.52$ to 0.24$)$ & 0.652 & 1.75 \\
Complications & $-0.23(-0.72$ to 0.39$)$ & 0.409 & 1.49 \\
The cyst index & $0.25(-0.59$ to 0.97$)$ & 0.509 & 1.36 \\
Healing of the cyst & $-0.05(-0.06$ to -0.03$)$ & $<0.001$ & 1.59 \\
Duration of hospitalization & $0.07(0.04$ to 0.13$)$ & $<0.001$ & 1.85 \\
\hline $\mathrm{R}$ & 0.78 & & \\
$\mathrm{R}^{2}$ & 0.61 & & \\
Overall $\mathrm{p}$ value & $<0.001$ & & \\
\hline
\end{tabular}

$95 \% \mathrm{CI}=95 \%$ confidence interval
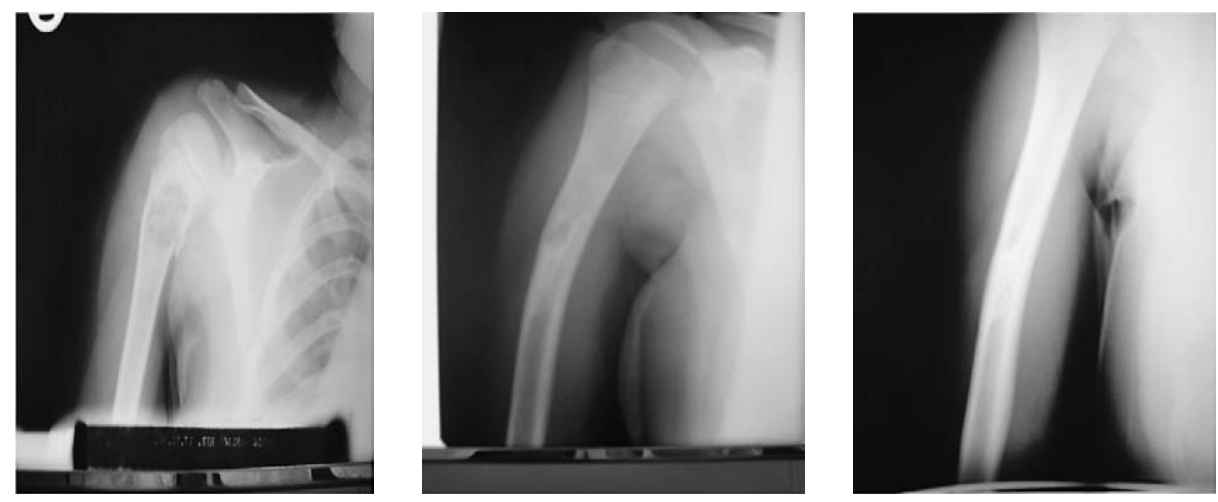

Fig. 1. Results of treatment using Scaglietti procedure (before treatment, 6 months and 12 months after treatment) $(A, B, C)$.
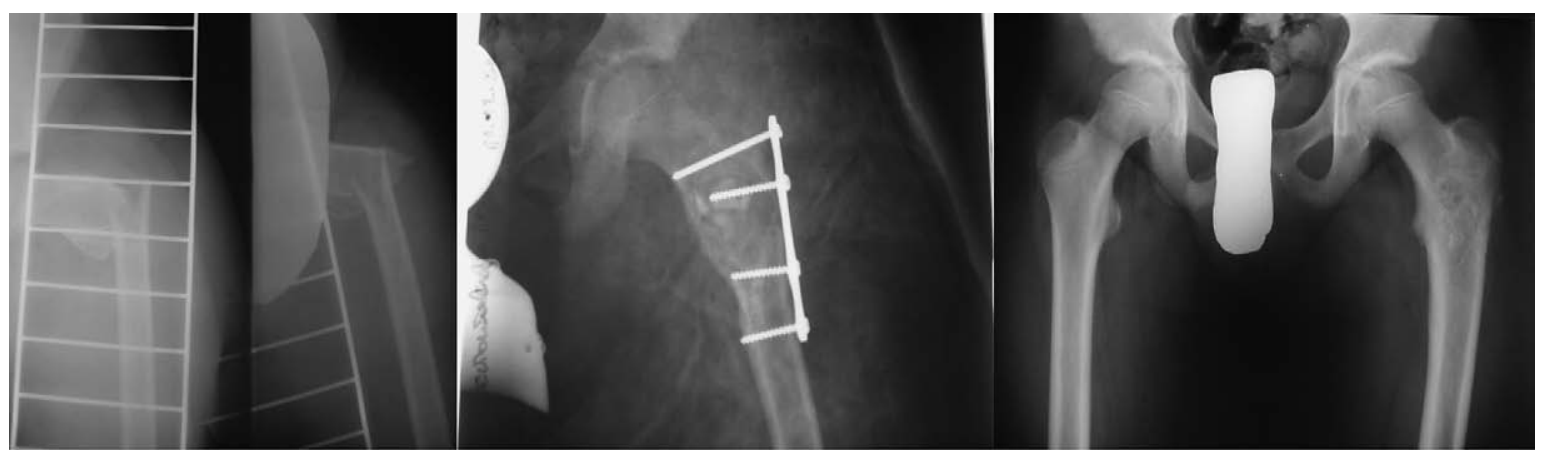

Fig. 2. Results of treatment using curettage and bone grafting (before treatment, after surgery and 12-month follow up) $(A, B, C)$. 


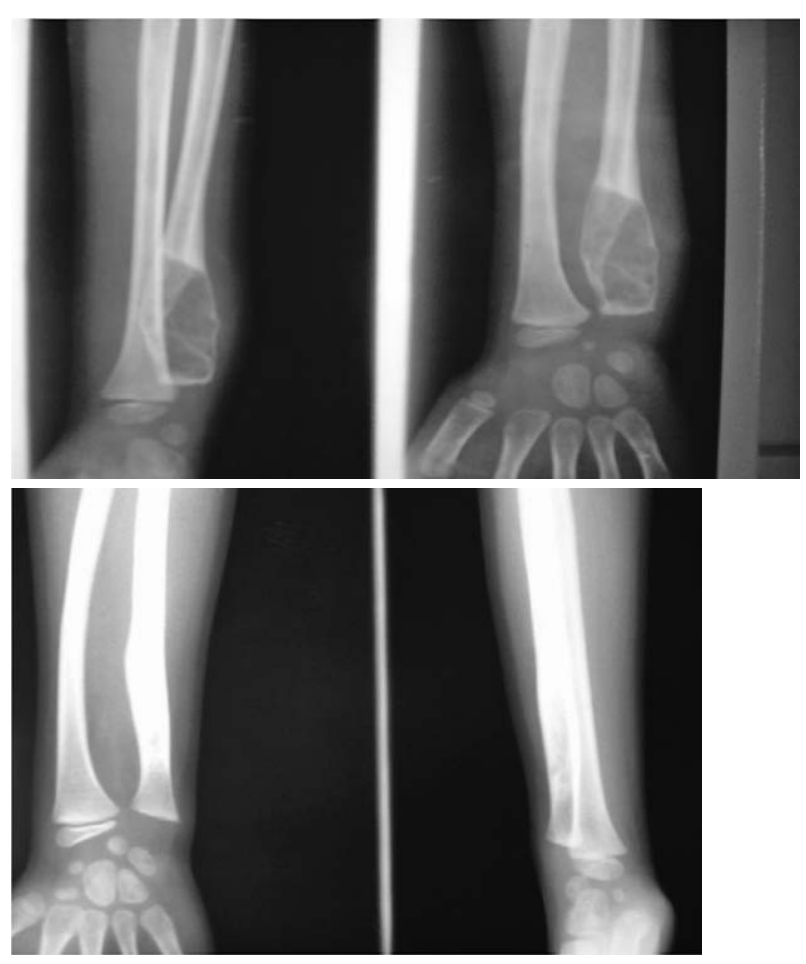

Fig. 3. Results of treatment using osteoinductive procedure (before treatment and 12-month follow up) (A, B).

into the cyst (group 1), while the period of cyst healing was shortest in patients treated by osteoinductive procedure (group 3). However, the latter had the longest duration of hospital treatment. Considering correlation coefficient (R-value), there was no correlation between independent values $(\mathrm{R}=0.78)$. Also, correlation coefficient $\left(\mathrm{R}^{2}\right)$ explained that $61 \%$ of all study variables could correlate with treatment options, and overall $\mathrm{p}$-value indicated statistical significance of the parameters observed $(\mathrm{p}<0.001)$ (Table 2$)$.

\section{Discussion}

The etiology and pathogenesis of UBC remain unclear. The most common hypothesis includes increasing intracystic pressure caused by venous obstruction in combination with the release of lytic enzymes (prostaglandin E2 and interleukin 1 $\beta$ ) produced by the cyst membrane ${ }^{2,7,8}$.

Treatment options for UBC are various, from percutaneous to open methods of treatment. Intracystic corticosteroid injections according to Scaglietti et al. reduce prostaglandin E2 production ${ }^{4}$. Canavese et al. point to the importance of cystic membrane destruction, which leads to healing of the cyst ${ }^{9}$. Sakamoto et al. report on the healing effect of cyst curettage ${ }^{10}$. Open curettage in combination with bone grafting is still widely used ${ }^{5,11}$. Also widely used is DBM injection to stimulate bone production, but this technique has no effect on the cyst membrane ${ }^{12-14}$. All these methods of treatment are associated with cyst recurrence, partial healing or healing with residual lesions ${ }^{6,15-19}$.

In our study, we compared three methods of treatment, i.e. minimally invasive Scaglietti procedure (group 1), curettage and autologous bone grafting (group 2) and osteoinductive procedure using DBM (group 3). Group 1 (Scaglietti procedure) was associated with a minimal risk of intraoperative or perioperative complications (no complications), short hospital stay (3.23 days) and treatment of small cysts $(<5 \mathrm{~cm}$ long) of long bones. The mean time of cyst healing according to Neer and Cole (grades I and II) for Scaglietti procedure was 29.78 months, which was statistically significantly different from osteoinductive procedure using DBM (19.25 months). The majority of bone cysts with presentation of pathologic fractures were treated using DBM implantation procedure (41.7\%), which was statistically significantly different from Scaglietti and bone grafting groups. Considering the length of hospital stay expressed in days, we found statistically significantly different results for the treatment options used in the study. In the group of patients undergoing Scaglietti procedure (group 1), the mean hospital stay was 3.23 days, as compared with surgically treated patients (groups 2 and 3), where the length of hospital stay was 9.40 and 9.92 days, respectively.

Hou et al. compared four different techniques of treatment in $40 \mathrm{UBC}$ patients, as follows: group 1 treated with MPA injection and autogenous bone marrow, group 2 treated with open curettage and grafting using DBM, group 3 treated with open curettage, DBM grafting and internal instrumentation, and group 4 treated with curettage, ethanol cauterization, disruption of the cystic margin, DBM insertion and placement of cannulated screw. Radiographically determined healing was $33 \%$ in group 1, 66\% in group 2, $100 \%$ in group 3 and $92 \%$ in group 4 . The rate of complete healing after curettage and grafting was $76.1 \%$. Expressed in time (months), healing took 23.4 months in group 1, 12.2 months in group 2, 6.6 months in 
group 3 and 3.7 months in group $4^{15}$. Comparing the results of this study with ours we found similar final outcome concerning healing period in our group of patients treated by use of Scaglietti procedure (29.78 months), but much longer healing period in patients treated by curettage and bone grafting (20.22 months) and those undergoing curettage and DBM implantation (19.25 months). However, compared to our study, limitations in the study by Hou et al. ${ }^{15}$ were a small number of participants (40 vs. 129 patients) and short follow up period (18-84 months vs. 30-240 months).

The study by Donaldson and Wright evaluated healing period in the treatment of UBC in 37 patients. The mean patient age was $17.2 \pm 3.2$ years and they were followed up for $7.0 \pm 1.0$ years. The authors compared healing period and complication rate in patients treated with open curettage and bone grafting and patients treated using curettage, bone grafting and intramedullary fixation. Restoration was fast in both groups, i.e. within 3 months of treatment, but patients with intramedullary fixation completed functional recovery faster, especially in association to previous pathologic fractured bones. The complication rate was $21.6 \%$ $(8 / 37)$ for all participants and they included mild bone deformities (7/37) and malunion (1/37) ${ }^{20}$.

\section{Conclusion}

This study compared the minimally invasive procedure and open surgery using bone grafting or DBM. Open surgery procedure using curettage of intracystic membrane and implantation of bone graft or DBM were the most reliable procedures in the treatment of UBC. We believe that complete healing of UBC can only be achieved using open surgery, thus additionally preventing the possible risk of residual lesions and fractures during skeletal maturation. The minimally invasive method using MPA intracystic instillation is associated with short hospital stay, less intra-hospital costs and complications but also has long healing period correlated to activity restriction and second surgery. Thus, MPA intracystic instillation can be considered a good option for initial treatment of long bone UBC.

\section{References}

1. Urakawa H, Tsukushi S, Hosono K, Sugiura H, Yamada K, Yamada $\mathrm{Y}$, et al. Clinical factors affecting pathological fracture and healing of unicameral bone cysts. BMC Musculoskelet Disord. 2014;15:159-67. http://dx.doi.org/10.1186/1471-24 74-15-159

2. Chigira M, Maehara S, Arita S, Udagawa E. The aetiology and treatment of simple bone cysts. J Bone Joint Surg Br. 1983;65(5):633-7. http://dx.doi.org//10.1302/0301-620X.65 B5.6643570

3. Neer CS, Francis KC, Johnston AD, Kiernan HA Jr. Current concept on the treatment of solitary unicameral bone cyst. Clin Orthop Relat Res. 1973;97:40-51. http://dx.doi.org/10.1097 /00003086-197311000-00008.

4. Scaglietti O, Marchetti PG, Bartolozzi P. The effects of methylprednisolone acetate in the treatment of bone cysts. Results of three year follow-up. J Bone Joint Surg Br. 1979;61-B(2): 200-4.

5. Neer CS, Francis KC, Marcove RC, Lerz J, Carbonara PN. Treatment of unicameral bone cyst. A follow-up study of one hundred seventy-five cases. J Bone Joint Surg Am. 1966;48(4): 731-45.

6. Wright JG, Yandow S, Donaldson S, Marley L. A randomized clinical trial comparing intralesional bone marrow and steroid injections for simple bone cysts. J Bone Joint Surg Am. 2008;90(4):722-30. http://dx.doi.org/10.2106/JBJS.G.00620.

7. Jaffe H, Lichtenstein L. Solitary unicameral bone cyst, with emphasis on the roentgen picture, pathologic appearance and pathogenesis. Arch Surg. 1942;44:1001-25.

8. Watanabe H, Arita S, Chigira M. Aetiology of a simple bone cyst. A case report. Int Orthop. 1994;18:16-9. http://dx.doi. org/10.1007/bf00180172.

9. Canavese F, Wright JG, Cole WG, Hopyan S. Unicameral bone cysts: comparison of percutaneous curettage, steroid, and autologous bone marrow injections. J Pediatr Orthop. 2011;31:50-5. http://dx.doi.org/10.1097/BPO.0b013e3181ff7510.

10. Sakamoto A, Matsuda S, Yoshida T, Iwamoto Y. Clinical outcome following surgical intervention for a solitary bone cyst: emphasis on treatment by curettage and steroid injection. J Orthop Sci. 2010;15:553-9. http://dx.doi.org/10.1007/s00776010-1485-x.

11. Oppenheim WL, Galleno H. Operative treatment versus steroid injection in the management of unicameral bone cysts. J Pediatr Orthop. 1984;4:1-7.

12. Rougraff BT, Kling TJ. Treatment of active unicameral bone cysts with percutaneous injection of demineralized bone matrix and autogenous bone marrow. J Bone Joint Surg Am. 2002; 84-A:921-9. http://dx.doi.org/10.2106/00004623-200206000 -00005 .

13. Killian JT, Wilkinson L, White S, Brassard M. Treatment of unicameral bone cyst with demineralized bone matrix.J Pediatr Orthop. 1998;18:621-4.

14. Chang CH, Stanton RP, Glutting J. Unicameral bone cysts treated by injection of bone marrow or methylprednisolone. J Bone Joint Surg Br. 2002;84:407-12.

15. Hou HY, Wu K, Wang CT, Chang SM, Lin WH, Yang RS. Treatment of unicameral bone cyst: a comparative study of selected techniques. J Bone Joint Surg Am. 2010;92:855-62. http://dx.doi.org/10.2106/JBJS.I.00607. 
16. Cho HS, Oh JH, Kim HS, Kang HG, Lee SH. Unicameral bone cysts: a comparison of injection of steroid and grafting with autologous bone marrow. J Bone Joint Surg Br. 2007; 89:222-6.

17. Hunt KJ, Bergeson A, Coffin CM, Randall RL. Percutaneous curettage and bone grafting for humeral simple bone cysts. Orthopedics. 2009;32(2):89.

18. Mik G, Arkader A, Manteghi A, Dormans JP. Results of a minimally invasive technique for treatment of unicameral bone cysts. Clin Orthop Relat Res. 2009;467:2949-54. http://dx.doi. org/10.1007/s11999-009-1008-2.

19. Schreuder HW, Conrad EU $3^{\text {rd }}$, Bruckner JD, Howlett AT, Sorensen LS. Treatment of simple bone cysts in children with curettage and cryosurgery. J Pediatr Orthop. 1997;17:814-20.

20. Donaldson S, Wright JG. Simple bone cysts: better with age? J Pediatr Orthop. 2015;35:108-14. http://dx.doi.org/10.1097/ BPO.0000000000000336.

Sažetak

\section{LIJEČENJE JEDNOKOMORNIH KOŠTANIH CISTA KOD DJECE: KOMPARATIVNA STUDIJA}

\section{B. Bukva, G. Vrgoč, D. Abramović, S. Dučic, I. Brkići T. Čengić}

Solitarne koštane ciste (SKC) su dobroćudne koštane lezije slične tumorima. Najčešće su lokalizirane u metafizno-dijafiznoj regiji dugih kostiju djece i adolescenata. Etiologija SKC nije razjašnjena. Ne postoji konsenzus o protokolu liječenja SKC. Cilj studije bio je procijeniti učinkovitost tri različite tehnike liječenja SKC. Studija je obuhvatila 129 bolesnika liječenih u Sveučilišnoj dječjoj bolnici u Beogradu tijekom 8 godina (2007.-2014.). Srednje razdoblje praćenja bilo je 7,14 (2,5-10) godina. Parametri za uključivanje bili su: spol, dob, lokacija ciste, veličina ciste, indeks ciste, debljina korteksa, patološka fraktura, cijeljenje ciste, komplikacije liječenja i trajanje hospitalizacije. Usporedili smo navedene parametre s tri različite tehnike liječenja: apliciranje metilprednisolon acetata (MPA) unutar ciste (skupina 1), kiretaža i umetanje koštanog presatka (skupina 2) i osteoinduktivni postupak upotrebom demineralizirane koštane međustanične tvari (DKM) (skupina 3). Utvrđena je statistički značajna razlika u cijeljenju cista i trajanju hospitalizacije između skupina 1 i 2 te između skupina 2 i 3 . U zaključku, potpuno liječenje SKC može se jedino postići otvorenom kirurškom tehnikom i time spriječiti mogući rizik od zaostalih lezija i fraktura. Minimalno invazivna metoda aplikacijom MPA unutar ciste može se smatrati dobrom opcijom za početno liječenje SKC dugih kostiju.

Ključne riječi: Koštane ciste; Dijete; Injekcije, intralezijske; Koštana transplantacija; Koštani matriks 